\title{
Antibacterial activity of Curcuma longa, Opuntia ficus- indica and Linum usitatissimum
}

\begin{abstract}
Extensive research is being conducted to investigate the various characteristics of medicinal plants and their potential for use as alternative and safe treatment against bacteria and other microorganisms. Curcuma longa (curcumin), Opuntia ficus-indica (cactus) and Linum usitatissimum (flaxseed) are three widely available medicinal plants that are used in several countries for treating a wide variety of health problems. This study was designed to test the ability of crude, aqueous and methanolic extracts of these plants to inhibit the growth of four multi-resistant clinical bacterial isolates: Staphylococcus aureus, Escherichia coli, Klebsiella pneumoniae and Pseudomonas aeruginosa. The results showed that the crude and aqueous extracts of $O$. ficus-indica were capable of inhibiting the growth of all the tested bacterial strains at a concentration of $0.1 \mathrm{mg} / \mathrm{ml}$. The crude and aqueous extracts of C. longa and L. usitatissimum did not show any inhibitory effect on the growth of any of the bacterial strains, at the concentrations used in the study. The methanolic extract only of Curcuma longa was capable of inhibiting the growth of all the bacterial strains used starting from a concentration of $0.25 \mathrm{mg} / \mathrm{ml}$, with an increasing inhibitory effect with the increase in the concentration of the extract. The methanolic extract of $O$. ficus-indica had no inhibitory effect on the growth of any of the bacterial strains while the methanolic extract of L. usitatissimum enhanced the growth of all of the bacterial strains when the concentration of the extract was $0.15 \mathrm{mg} / \mathrm{ml}$ or more. Further work is recommended to build up on the results reported in this study.
\end{abstract}

Keywords: antibacterial effect, aqueous extraction, curcumin, cactus, flaxseeds, medicinal plants, methanol extraction
Volume 4 Issue 3 - 2018

\author{
Patrick Abou Raji El Feghali, Riwa Ibrahim, \\ Tarek Nawas \\ Department of Natural Sciences, Lebanese American University, \\ Lebanon
}

\author{
Correspondence: Tarek Nawas, Department of Natural \\ Sciences, School of Arts and Sciences, Lebanese American \\ University, Beirut, Lebanon, Tel +96II 8676 I8, \\ Email tnawas@lau.edu.lb
}

Received: May 26, 2018 | Published: June II, 2018

\section{Introduction}

According to the World Health Organization, antibiotics, along with other antimicrobial agents, made medical procedures such as organ transplant, cancer chemotherapy, and major surgery relatively safe, however, the misuse of those agents resulted in the emergence and spread of antimicrobial resistance. ${ }^{1}$ Resistant microorganisms demonstrate decreased sensitivity to antimicrobial agents, thus making the treatment and prevention of bacterial, fungal, parasitic and viral infections difficult. Another important concern is the fact that most of these agents are often associated with adverse side-effects on the host; increasing the risk of complications that could sometimes be deadly. ${ }^{2}$ These issues directed the attention of researchers towards traditional ethnobotanical treatment. Extensive research is being conducted to investigate the pharmaceutical effects of medicinal plants and their potential use as an alternative and safe treatment against bacteria and other microorganisms. Of these plants, three have been of special interest: Curcuma longa (curcumin), Opuntia ficus-indica (cactus), and Linum usitatissimum (flaxseed). Curcuma longa, commonly known as curcumin or turmeric, is a plant that belongs to the Zingiberaceae family. ${ }^{3}$ Its rhizomes are thick and fleshy, elongated in shape and surrounded by a rough segmented skin. It has a yellowishbrown color with a pale orange color on the inside. ${ }^{2}$ The length of the root varies from $2.5 \mathrm{~cm}$ to $7 \mathrm{~cm}$, and the diameter of the main root is generally around $2.5 \mathrm{~cm}$. The plant is native to Southern Asia, and is widely cultivated in the warm areas of the world namely in India, as well as other countries including China, Taiwan, Sri Lanka, Peru and Australia. ${ }^{4}$ C. longa is used for several purposes in medicine, cosmetics, food flavoring and textile industries. It has been shown to exhibit major pharmacological activities which include antimicrobial, hepatoprotective, antioxidant, antitumor, wound healing and antiviral effects. ${ }^{5}$ Furthermore, it displayed important therapeutic effects against cardiovascular, pulmonary, metabolic, neurodegenerative and autoimmune diseases. ${ }^{6}$ The herb is also prescribed for the treatment of a wide range of health issues related to the digestive tract. ${ }^{7}$ C. longa has also shown significant antibacterial activity against several strains of both Gram positive and Gram-negative bacteria. ${ }^{8}$ The aqueous extract of $C$. longa showed antibacterial activity against Escherichia coli, Staphylococcus aureus, and Staphylococcus epidermidis, and Klebsiella pneumonia. ${ }^{5}$ An alcoholic extract of $C$. longa inhibited growth of most microorganisms occurring in cholecystitis including Sarcinia, Gaffkya, Corynebacterium, Streptococcus, and Bacillus strains. ${ }^{9}$ The methanol extract of turmeric revealed an inhibitory effect against Bacillus subtilis and S. aureus, respectively. ${ }^{10}$ The study of hexane and ethanol turmeric extract showed antibacterial activity against 13 bacteria, namely, Vibrio harveyi, Vibrio alginolyticus, Vibrio vulnificus, Vibrio parahaemolyticus, Vibrio cholerae, Bacillus subtilis, Bacillus cereus, Aeromonas hydrophila, Streptococcus agalactiae, Staphylococcus aureus, Staphylococcus intermedius, Staphylococcus epidermidis, and Edwardsiella tarda. ${ }^{10}$

The dicotyledonous angiosperms of the family Cactaceae include around 1500 species of cactus, including Opuntia ficus-indica, generally known as prickly pear or nopal cactus. It is mostly found in tropical and subtropical areas characterized by arid or semiarid climates. Notable examples include Mexico, Latin America, South Africa and Mediterranean countries. ${ }^{11}$ The two betalain pigments present in the prickly pear fruits are responsible for their color that can vary between: yellow, orange, red, purple and white. ${ }^{12}$ This difference in color is also an indicator of the nutritional and antioxidant properties 
of the fruit. ${ }^{13}$ Juices, alcoholic beverage, jams and natural sweeteners are produced from the prickly pear fruit. ${ }^{11,14} \mathrm{O}$. ficus-indica was used in traditional medicine when dealing with burns, wounds, obesity, hyperlipidemia, edema and catarrhal gastritis. Furthermore, alcoholic extracts showed anti-inflamatory, hypoglycemic, and antiviral activities. ${ }^{15}$ Its curative potential was mentioned for metabolic syndromes including diabetes type 2 and obesity, non-alcoholic fatty liver disease (NAFLD), rheumatism, cancer, cerebral ischemia and viral and bacterial infections. ${ }^{16}$ Cactus cladodes were shown to present effective cures for gastritis, hyperglycemia, hypercholesterolemia, arteriosclerosis, diabetes, prostatic hypertrophy. ${ }^{17}$ Furthermore, cladodes displayed a hypolipidemic effect. Extracts of $O$. ficusindica were shown to exhibit antibacterial effects on the growth of Campylobacter jejuni and Campylobacter coli. Furthermore, a strong reduction in the adherence of Campylobacter to Vero cells was reported. ${ }^{18}$ Methanolic, ethanolic and aqueous extracts of $O$. ficusindica were tested for antibacterial activity against Vibrio cholera and it was reported that the methanolic extract was the most efficient. ${ }^{19}$ Antimicrobial activity was noted versus Staphylococcus aureus, Pseudomonas aeruginosa and Escherichia coli; in addition to a strong antifungal effect also noted against Aspergillus niger. Furthermore, $O$. ficus-indica was found to exhibit a significant bactericidal effect against Enterococcus faecium and was able to slightly inhibit the growth of Candida albicans. ${ }^{20}$

Linum usitatissimum, which belongs to the Linaceae family, is also known as flaxseed, common flax or linseed and is becoming one of the most important and attention-grabbing functional foods. The original source of this plant is the area extending from the Middle East to India and from Western Asia to the Eastern Mediterranean. ${ }^{21}$ In the past, the use of flaxseed was limited to the fabrication of cloth and manufacturing papers; however, nowadays it is planted over more than 2.6million Hectares in different countries including the United States, China and Canada for different uses in the industry. ${ }^{22}$ Flaxseed contains many functional ingredients that are considered to be important in the field of healthy diet. These ingredients include: polyunsaturated fatty acids, specifically members of the omega three family, carbohydrates, proteins, lignans and fibers. The attention of most studies is shifted towards omega three fatty acids and their importance in protection against certain infections and their potential for use in treatment of many conditions such as migraine, headache, attention hyperactivity/ deficiency, Lyme disease, glaucoma, preterm labor, panic attacks and many other conditions. ${ }^{23}$ The amino acid sequences of the proteins found in flaxseed is comparable with that of proteins found in soybean which is considered a very important nutritional plant protein. ${ }^{24}$ Bhathena and his colleagues in 2003 also showed that flaxseed has an effect on decreasing the plasma triglyceride. ${ }^{25}$ Flaxseed is considered to be a fiber rich diet. These fibers are either soluble or insoluble. Fibers in flaxseed were also shown to have an impact on health through the repression of hunger and the decrease of nutrients absorption, which combined affect body weight. ${ }^{26}$ Flaxseeds are considered a rich source of phenolic compounds containing many bioactive phenolic compounds including: lignans, flavonoids and phenolic acids. ${ }^{27,28}$ In general flaxseed has an anti-proliferation effect, a reason why it was suggested to have a protective effect against hormone dependent tumors and was linked to decreasing the risk of post-menopausal breast cancer. ${ }^{29}$ The purpose of this study was to investigate the ability of crude, aqueous and methanol extracts of C. longa, O. ficus-indica and $L$. usitatissimum to affect the growth of four clinically significant organisms: S. aureus, E. coli, K. pneumoniae and P. aeruginosa.

\section{Methods}

\section{Sources of plants used}

Samples of C. longa and L. usitatissimum were purchased from a local beans shop. Fresh samples of the cladodes of the plant, O. ficus-indica, which grows in the wild, were obtained from the Wadi Chahrour region of Mount Lebanon. All samples were identified by our reference botanist and then immediately sent to the microbiology laboratory for processing.

\section{Bacterial isolates}

The bacterial isolates used in the study were clinical bacterial isolates courteously provided by the Clinical Microbiology Laboratory of the Lebanese American University Medical Center Rizk Hospital (LAUMC- RH). Specifically, the isolates used were multi-resistant strains of the following organisms: Staphylococcus aureus, Escherichia coli, Klebsiella pneumoniae and Pseudomonas aeruginosa. The identity of the isolates was confirmed by the use of standard tests..$^{30}$ The definitive identification of the Enterobacteriaceae isolates was also done using the API 20E kits (Biomerieux-France).

\section{Preparation of the crude extracts}

Two hundred grams of each of the Opuntia ficus-indica cladodes, Curcuma longa roots and the Linum usitatissimum seeds were weighed using a mass balance. The cladode of Opuntia ficus-indica, roots of Curcuma longa and seeds of Linum usitatissimum were chopped and blended well for use in the different experiments.

\section{Preparation of the aqueous extracts}

Two hundred grams of each of the Opuntia ficus-indica cladodes, Curcuma longa roots and the Linum usitatissimum seeds were weighed using a mass balance. The cladode of Opuntia ficus-indica, roots of Curcuma lunga and seeds of Linum usitatissimum were boiled in 1 liter of water until the liquid became thick. A portion of the extract was autoclaved while the other was kept not autoclaved, for use in the different experiments.

\section{Preparation of the methanol extracts}

Two hundred grams of each of the Opuntia ficus-indica cladodes, Curcuma longa roots and the Linum usitatissimum seeds were weighed using a mass balance, chopped and mixed with $80 \%$ methanol in a sterile blender. The extract was then transferred to several Erlenmeyer flasks, kept in an orbital shaker for 1 week and then filtered using vacuum assisted Millipore filtration. Rotary evaporation was performed on the extracts, in order to evaporate all the remaining methanol.

\section{Preparation of the extract containing test plates}

Mueller-Hinton agar (MHA) was prepared as recommended by the manufacturer. A portion of the agar was poured in a petri dish to be used as control. Different concentrations of the extracts were later added to the partially cooled, but melted MHA in different Erlenmeyer flasks and then dispensed in petri dishes.

\section{Seeding of the extract containing test plates with the test organisms}

A fresh inoculum of each of the test organisms was aseptically transferred to sterile saline and the turbidity of the organisms adjusted 
to match a $0.5 \mathrm{McF}$ arland standard tube. Each of the prepared sets of plates was then seeded, using sterile swabs, with each of the test organisms. All the sets of plates were then incubated at $35 \mathrm{oC}$ for $24 \mathrm{hrs}$, after which the growth of the organisms was noted and recorded.

\section{Results}

At a concentration of $0.05 \mathrm{mg} / \mathrm{ml}$ of either unautoclaved crude or aqueous extract of $O$. ficus-indica, none of the bacteria used in the experiment was inhibited, however, at the same concentration but when both extracts were autoclaved, partial inhibition of all the bacteria used in the experiment was observed (Tables 1-4). When the concentration was raised to $0.1 \mathrm{mg} / \mathrm{ml}$, the autoclaved crude extract was also able to totally inhibit the growth of $S$. aureus, E. coli and $K$. pneumoniae (Tables 1-3), and partially inhibit the growth of $P$. aeruginosa (Table 4). Whereas the aqueous autoclaved extract totally inhibited the growth of all the bacteria used in the experiment (Tables 1-4). C. longa crude and aqueous, autoclaved and unautoclaved extracts didn't show any inhibitory effect at a concentration of $0.05 \mathrm{mg} / \mathrm{ml}$ on any of the bacteria used in the experiment (Tables $1-4$ ). However, when the concentration was increased to $0.1 \mathrm{mg} / \mathrm{ml}$, the autoclaved extract showed partial inhibition of all the bacteria used in the experiment (Tables 1-4). Nonetheless, at the same concentration, the unautoclaved extract didn't show any inhibitory effect on any of the bacteria used in the experiment (Tables -4). L. usitatissimum extracts, whether crude or aqueous, autoclaved or unautoclaved, at any concentration, were not able to inhibit the growth of any of the bacteria used in this experiment (Tables 1-4) The methanolic extracts of $O$. ficus-indica were not able to inhibit any of the bacteria used in the experiment at the concentrations of $0.025 \mathrm{mg} / \mathrm{ml}$ and $0.05 \mathrm{~g} / \mathrm{ml}$ (Tables 5-8). When the concentration increased to $0.1 \mathrm{mg} /$ $\mathrm{mL}, O$. ficus-indica was partially capable of inhibiting the growth of S. aureus and E. coli (Tables 5) (Table 6) but was not capable of inhibiting the growth of $K$. pneumoniaea or P. aeruginosa (Table 7) (Table 8). At concentrations of $0.15 \mathrm{mg} / \mathrm{ml}, 0.18 \mathrm{mg} / \mathrm{ml}$ and $0.25 \mathrm{mg} / \mathrm{ml}$ $O$. ficus-indica was partially capable of inhibiting the growth of all the bacteria used in the experiment (Tables 5-8). On the other hand, the methanolic extracts of $C$. long $a$ at concentrations of $0.025 \mathrm{mg} / \mathrm{ml}$ and $0.05 \mathrm{mg} / \mathrm{ml}$ did not show inhibition of any of the bacteria tested (Tables 5-8), however, when the concentration were increased to $0.1 \mathrm{mg} / \mathrm{ml}$, C. longa partially inhibited the growth of $S$. aureus, E. coli and $K$. pneumoniae (Tables 5-7), but did not inhibit the growth of P. aeruginosa (Table 8). At a concentration of $0.15 \mathrm{mg} / \mathrm{ml}$, C. longa was able to inhibit totally the growth of $K$. pneumoniae (Table 7) and partially that of $S$. aureus, E. coli and P. aeruginosa (Tables 5, $6 \& 8$ ). When the concentration of $C$. longa extract was increased to $0.18 \mathrm{mg} / \mathrm{ml}$, both $S$. aureus and $K$. pneumoniae were totally inhibited (Table 6) (Table 7) whereas E. coli and P. aeruginosa were partially inhibited (Table 5) (Table 8). The concentration of $0.25 \mathrm{mg} / \mathrm{ml}$ was enough to inhibit the growth of all the bacteria used in this experiment (Tables 5-8). The methanolic extracts of L. usitatissimum did not inhibit the growth of any of the bacteria used in the experiment at any concentration. However, at extract concentrations of $0.15 \mathrm{mg} /$ $\mathrm{ml}, 0.18 \mathrm{mg} / \mathrm{ml}$ and $0.25 \mathrm{mg} / \mathrm{ml}$, the growth of the different bacterial strains was enhanced (Tables 5-8).

Table I The effect of the three aqueous and crude extracts on the growth of Staphylococcus aureus

\begin{tabular}{|c|c|c|c|c|c|c|c|c|c|}
\hline & \multirow{3}{*}{ Control } & \multicolumn{4}{|c|}{ Aqueous } & \multicolumn{4}{|l|}{ Crude } \\
\hline & & \multicolumn{2}{|c|}{ Autoclaved } & \multicolumn{2}{|c|}{ Unautoclaved } & \multicolumn{2}{|c|}{ Autoclaved } & \multicolumn{2}{|c|}{ Unautoclaved } \\
\hline & & $\begin{array}{l}0.05 \\
\mathrm{mg} / \mathrm{ml}\end{array}$ & $\begin{array}{l}0.1 \\
\mathrm{mg} / \mathrm{ml}\end{array}$ & $\begin{array}{l}0.05 \\
\mathrm{mg} / \mathrm{ml}\end{array}$ & $0.1 \mathrm{mg} / \mathrm{ml}$ & $\begin{array}{l}0.05 \\
\mathrm{mg} / \mathrm{ml}\end{array}$ & $0.1 \mathrm{mg} / \mathrm{ml}$ & $\begin{array}{l}0.05 \\
\mathrm{mg} / \mathrm{ml}\end{array}$ & $0.1 \mathrm{mg} / \mathrm{ml}$ \\
\hline O. ficus-indica & +++ & + & - & +++ & ++ & ++ & - & +++ & ++ \\
\hline C. longa & +++ & +++ & ++ & +++ & +++ & +++ & ++ & +++ & +++ \\
\hline L. usitatissimum & +++ & +++ & +++ & +++ & +++ & +++ & +++ & +++ & +++ \\
\hline
\end{tabular}

-, No growth; +, weak growth; ++, moderate growth; +++: confluent growth

Table 2 The effect of the three aqueous and crude extracts on the growth of Escherichia coli

\begin{tabular}{|c|c|c|c|c|c|c|c|c|c|}
\hline & \multirow{3}{*}{ Control } & \multicolumn{4}{|c|}{ Aqueous } & \multicolumn{4}{|l|}{ Crude } \\
\hline & & \multicolumn{2}{|c|}{ Autoclaved } & \multicolumn{2}{|c|}{ Unautoclaved } & \multicolumn{2}{|c|}{ Autoclaved } & \multicolumn{2}{|c|}{ Unautoclaved } \\
\hline & & $\begin{array}{l}0.05 \\
\mathrm{mg} / \mathrm{ml}\end{array}$ & $\begin{array}{l}0.1 \mathrm{mg} / \\
\mathrm{ml}\end{array}$ & $\begin{array}{l}0.05 \\
\mathrm{mg} / \mathrm{ml}\end{array}$ & $\begin{array}{l}0.1 \\
\mathrm{mg} / \mathrm{ml}\end{array}$ & $\begin{array}{l}0.05 \\
\mathrm{mg} / \mathrm{ml}\end{array}$ & $\begin{array}{l}0.1 \\
\mathrm{mg} / \mathrm{ml}\end{array}$ & $\begin{array}{l}0.05 \\
\mathrm{mg} / \mathrm{ml}\end{array}$ & $\begin{array}{l}0.1 \\
\mathrm{mg} / \mathrm{ml}\end{array}$ \\
\hline O. ficus-indica & +++ & ++ & - & +++ & ++ & + & - & +++ & ++ \\
\hline C. longa & +++ & +++ & + & +++ & +++ & +++ & ++ & +++ & +++ \\
\hline L. usitatissimum & +++ & +++ & +++ & +++ & +++ & +++ & +++ & +++ & +++ \\
\hline
\end{tabular}

-, No growth; +, weak growth; ++, moderate growth; +++: confluent growth 
Table 3 The effect of the three aqueous and crude extracts on the growth of Klebsiella pneumoniae

\begin{tabular}{|c|c|c|c|c|c|c|c|c|c|}
\hline & \multirow[b]{3}{*}{ Control } & \multicolumn{4}{|c|}{ Aqueous } & \multicolumn{4}{|l|}{ Crude } \\
\hline & & \multicolumn{2}{|c|}{ Autoclaved } & \multicolumn{2}{|c|}{ Unautoclaved } & \multicolumn{2}{|c|}{ Autoclaved } & \multicolumn{2}{|c|}{ Unautoclaved } \\
\hline & & $\begin{array}{l}0.05 \\
\mathrm{mg} / \mathrm{ml}\end{array}$ & $0.1 \mathrm{mg} / \mathrm{ml}$ & $\begin{array}{l}0.05 \\
\mathrm{mg} / \mathrm{ml}\end{array}$ & $0.1 \mathrm{mg} / \mathrm{ml}$ & $\begin{array}{l}0.05 \\
\mathrm{mg} / \mathrm{ml}\end{array}$ & $\begin{array}{l}0.1 \\
\mathrm{mg} / \mathrm{ml}\end{array}$ & $\begin{array}{l}0.05 \\
\mathrm{mg} / \mathrm{ml}\end{array}$ & $\begin{array}{l}0.1 \\
\mathrm{mg} / \mathrm{ml}\end{array}$ \\
\hline O. ficus-indica & +++ & ++ & - & +++ & ++ & + & - & +++ & ++ \\
\hline C. longa & +++ & +++ & + & +++ & +++ & +++ & ++ & +++ & +++ \\
\hline L. usitatissimum & +++ & +++ & +++ & +++ & +++ & +++ & +++ & +++ & +++ \\
\hline
\end{tabular}

-, No growth; +, weak growth; ++, moderate growth; +++: confluent growth

Table 4 The effect of the Aqueous and crude three extracts on the growth of Pseudomonas aeruginosa

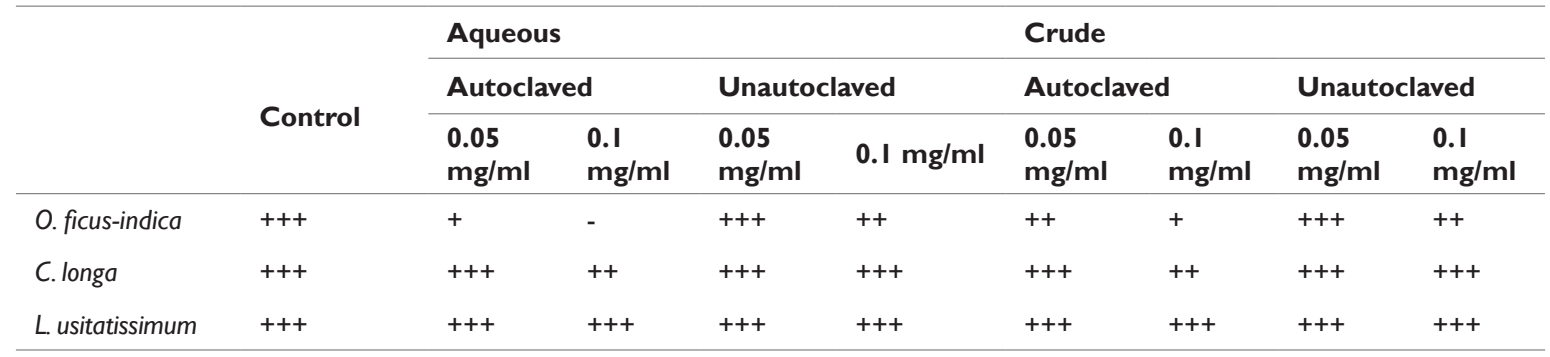

-, No growth; +, weak growth; ++, moderate growth; +++: confluent growth

Table 5 The effect of the three methanolic extracts on the growth of Staphylococcus aureus

\begin{tabular}{llllllll}
\hline & Control & $0.025 \mathrm{mg} / \mathrm{ml}$ & $0.05 \mathrm{mg} / \mathrm{ml}$ & $0.1 \mathrm{mg} / \mathrm{ml}$ & $0.15 \mathrm{mg} / \mathrm{ml}$ & $0.18 \mathrm{mg} / \mathrm{ml}$ & $0.25 \mathrm{mg} / \mathrm{ml}$ \\
\hline O. ficus-indica & +++ & +++ & +++ & +++ & ++ & ++ & ++ \\
C. longa & +++ & +++ & +++ & ++ & + & + & - \\
L. usitatissimum & +++ & +++ & +++ & +++ & ++++ & ++++ & +++
\end{tabular}

-, No growth; +, weak growth; ++, moderate growth; +++, confluent growth; ++++, enhanced confluent growth

Table 6 The effect of the three methanolic extracts on the growth of Escherichia coli

\begin{tabular}{|c|c|c|c|c|c|c|c|}
\hline & Control & $0.025 \mathrm{mg} / \mathrm{ml}$ & $0.05 \mathrm{mg} / \mathrm{ml}$ & $0.1 \mathrm{mg} / \mathrm{ml}$ & $0.15 \mathrm{mg} / \mathrm{ml}$ & $0.18 \mathrm{mg} / \mathrm{ml}$ & $0.25 \mathrm{mg} / \mathrm{ml}$ \\
\hline O. ficus-indica & +++ & +++ & +++ & ++ & ++ & ++ & + \\
\hline C. longa & +++ & +++ & ++ & + & + & _ & _ \\
\hline L. usitatissimum & +++ & +++ & +++ & +++ & ++++ & ++++ & ++++ \\
\hline
\end{tabular}

-, No growth; +, weak growth; ++, moderate growth; +++, confluent growth; ++++, enhanced confluent growth

Table 7 The effect of the three methanolic extracts on the growth of Klebsiella pneumoniae

\begin{tabular}{llllllll}
\hline & Control & $0.025 \mathrm{mg} / \mathrm{ml}$ & $\mathbf{0 . 0 5} \mathrm{mg} / \mathrm{ml}$ & $\mathbf{0 . 1} \mathbf{~ m g / m l}$ & $0.15 \mathrm{mg} / \mathrm{ml}$ & $0.18 \mathrm{mg} / \mathrm{ml}$ & $0.25 \mathrm{mg} / \mathrm{ml}$ \\
\hline O. ficus-indica & +++ & +++ & +++ & +++ & +++ & ++ & ++ \\
C. longa & +++ & +++ & +++ & + & - & - & - \\
L. usitatissimum & +++ & +++ & +++ & +++ & +++ & +++ & +++ \\
\hline
\end{tabular}

-, No growth; +, weak growth; ++, moderate growth; +++, confluent growth; ++++, enhanced confluent growth

Table 8 The effect of the three methanolic extracts on the growth of Pseudomonas aeruginosa

\begin{tabular}{llllllll}
\hline & Control & $0.025 \mathrm{mg} / \mathrm{ml}$ & $0.05 \mathrm{mg} / \mathrm{ml}$ & $0.1 \mathrm{mg} / \mathrm{ml}$ & $0.15 \mathrm{mg} / \mathrm{ml}$ & $0.18 \mathrm{mg} / \mathrm{ml}$ & $0.25 \mathrm{mg} / \mathrm{ml}$ \\
\hline O. ficus-indica & +++ & +++ & +++ & +++ & +++ & ++ & ++ \\
C. longa & +++ & +++ & +++ & +++ & ++ & + & - \\
L. usitatissimum & +++ & +++ & +++ & +++ & ++++ & +++ & ++++ \\
\hline
\end{tabular}

-, No growth; +, weak growth; ++, moderate growth; +++, confluent growth; ++++, enhanced confluent growth 


\section{Discussion}

The aqueous extract of $C$. longa did not have any major effect on the growth of the 4 bacterial strains used in this study. This might have been due to the fact that the bioactive material of interest may be thermolabile and thus denatured by boiling; despite the fact that traditional healers depend primarily on aqueous extracts. It was demonstrated, however, that organic extractants yielded more significant and consistent results with regards to antimicrobial activity. ${ }^{31}$ C. longa's main organic constituents include curcumin (diferuloylmethane), which makes up approximately $90 \%$ of these compounds, followed by demethoxycurcumin and bisdemethoxycurcmin. ${ }^{32}$ Curcumin has been under extensive research in the last few decades and showed antioxidant, antiviral, antifungal, ${ }^{33,34}$ and antibacterial activity. ${ }^{35-40}$ Furthermore, curcumin, $\mathrm{C}_{2} \mathrm{H}_{2} \mathrm{OO}_{6}$, whose melting point is $184^{\circ} \mathrm{C}$, was shown to exhibit high solubility in acetone and ethanol, while being insoluble in water. ${ }^{41}$ So this was probably the main reason that no inhibition was observed when testing with the $C$. longa aqueous extracts. On the other hand, the methanol extract of $C$. longa was found to be much more effective indicating that methanol is better than water as an extraction solvent of the antibacterial chemical component. In fact, most of the antimicrobial chemicals that were identified were water insoluble, which makes organic solvents more suitable for their extraction. ${ }^{42}$ At a concentration of $0.25 \mathrm{mg} / \mathrm{ml}$, the methanolic extract of C. longa was found to inhibit the growth of all the bacterial strains tested. This effect increased with the increase of the extract concentration, as expected. From minimal inhibition at $0.10 \mathrm{mg} / \mathrm{ml}, E$. coli and $K$. pneumoniae were both totally inhibited at concentrations of $0.18 \mathrm{mg} /$ $\mathrm{ml}$ and $0.15 \mathrm{mg} / \mathrm{ml}$ respectively. It was noted that even though the inhibition of growth was clearly observed at higher concentrations, the effect obviously started at lower concentrations. The fact that the bacterial strains did grow on lower concentrations doesn't necessarily mean that there was no effect, as it has been verified previously that numerous effects including: changing the bacterial morphology and growth, affecting bacterial virulence factors and altering bacterial susceptibility to host immune defenses were exhibited at subinhibitory antimicrobial concentrations. ${ }^{43}$

As for $O$. ficus-indica, the aqueous autoclaved extract had the most inhibitory effect on all the bacterial strains tested in the study. While weak to moderate growth was observed at a concentration of $0.05 \mathrm{mg} / \mathrm{ml}$, complete inhibition was observed at a concentration of $0.1 \mathrm{mg} / \mathrm{ml}$ for all the tested bacteria. This was an indication that $O$. ficus-indica flowers contained high amounts of polar components. The obtained results explained why the aqueous extract yield was significant. This could be attributed to the high dissolution capacity of the water; for as water presents with a high polarity index, dielectric constant and cohesive energy, compared with other solvents, it provides strong binding between water molecules and polar compounds from the solute, causing their dissolution. ${ }^{44}$ Moreover, analysis of the constituents of the cladodes of $O$. ficus-indica showed that it contained significant amounts of calcium oxalate crystals. It was demonstrated that calcium had an important role in water retention of succulent tissues and helped to regulate the osmotic pressure in the cells. Moreover, it was shown that the oxalate crystals' size increased as a function of maturation. ${ }^{45}$ The existence of calcium oxalate crystals probably limited the bioavailability of calcium, which probably explains the observed antibacterial effect of the aqueous extract of $O$. ficus -indica against all the bacterial strains tested. On the other hand, both the aqueous and crude extracts, of $O$. ficus-indica, that were not subjected to autoclaving had no inhibitory effect on any of the bacteria. This was probably due to the fact that autoclaving exposes the extracts to very high temperatures $\left(121^{\circ} \mathrm{C}\right)$ and high pressure (15psi) which lead to complete denaturation and degradation of almost all the organic matter present, leaving ions as the main potential effectors. The fact that the extracts were not autoclaved in this step, indicated that the organic matter was still present and thus, according to Fabrega (2009), it was capable of binding the ions lowering their antibacterial effect and their "toxicity" to bacteria. ${ }^{46}$

When the methanolic extract of $O$. ficus-indica was used, no inhibition of growth of any of the bacteria was observed. Phenols and flavonoids are bioactive compounds that were found to be present in $O$. ficus-indica and have been associated with restorative processes by their antimicrobial properties, abilities to reduce free radical formation and to scavenge free radicals. ${ }^{47-49}$ However, the efficacy of these phenolic compounds depended greatly on their physicochemical properties. In addition, these polyphenols were found to be unstable molecules, and are thus easily oxidized by air and light and consequently can lose their activity. ${ }^{50}$ This fact can probably explain the absence of any antibacterial effect when using the methanolic extract, as they might have been deactivated due to their exposure to excessive light, air, or other deactivating factors. The aqueous and crude extracts of flaxseeds, whether autoclaved or not autoclaved did not show any antibacterial activity against the bacterial strains tested. Moreover, the methanolic extract showed an enhancement of the growth of all the bacterial strains starting from a concentration of $0.15 \mathrm{mg} / \mathrm{ml}$. This probably was because 6 to $8 \%$ of the dry weight of the whole seed of flaxseed was that of a heterogenic polysaccharide, flaxseed mucilage/gum, a soluble fiber. ${ }^{51}$ This polysaccharide is part of a group of non-digestible polysaccharides, that also includes galacto-oligosaccharides, fructo-oligosaccharides and cyclodextrins. These polysaccharides are known to be prebiotic substances that selectively stimulate the growth and/or activity of the gastrointestinal micro-flora. ${ }^{52}$

It is worthwhile noting that the method used to detect the antibacterial effect in this study was standardized as much as possible to be compatible with the recommendations of the European Committee for Antimicrobial Susceptibility Testing (EUCAST). ${ }^{53}$ A standardized volume of Muller Hinton Agar was used and diluted with the different extracts to reach the desired concentrations and the bacterial inoculum used to seed the plates was that comparable with the adopted 0.5 Mcfarland standard. Preliminary studies on the methanolic extracts showed that methanol did interfere significantly with the bactericidal activity of the extracts, a reason why the rotary evaporation process was needed, in order to, make sure that all the methanol was evaporated for proper interpretation of the final results.

\section{Conclusion}

This study showed that $C$. longa contained organic components that evidently had an antibacterial effect. Although curcumin, its major constituent, was shown to exhibit antibacterial activity, further research is needed in order to determine whether there is additional substance that might be contributing to $C$. longa's antibacterial effect. The ionic constituents of $O$. ficus-indica were found to confer to it an effective antibacterial activity. So far, little research has been done on $O$. ficus-indica in order to determine any active substances that may also be causing its antibacterial activity. Identification of the active compounds of each plant, constitutes only the first step in 
the development of new antibacterial pharmaceuticals. Further steps include numerous biological trials, the determination of adequate dosing, and clinically oriented studies to establish the safety, efficacy and pharmacokinetic profile of any new drug. The evaluation of an extract on whole-organism systems is a crucial step in determining its effects on the host or on the normal microbiota, so that it can be used as a valid medicinal agent. ${ }^{54}$ The fact that the tested plants (mainly $C$. longa and $O$. ficus-indica), and their aqueous extracts, are commonly used by people without reported side effects, indicates that these extracts may be promising to use in vivo without any complications. Flaxseed, on the other hand, was shown to enhance bacterial growth due to its high polysaccharide content, ${ }^{51}$ so although it may not have antibacterial effects, it may prove to be very useful when the growth of bacteria is needs to be enhanced like in cases of disequilibrium in the normal microbiota.

\section{Acknowledgments}

None.

\section{Conflict of interest}

The author declares that there is no conflict of interest.

\section{References}

1. WHO Fact sheet: Antimicrobial resistance. Geneva: World Health Organization Media Centre; 2018.

2. Gupta A, Mahajan S, Sharma R. Evaluation of antimicrobial activity of Curcuma longa rhizome extract against Staphylococcus aureus. Biotechnol Rep (Amst). 2015;6:51-55.

3. Awasthi P, Dixit S. Chemical composition of Curcuma Longa leaves and rhizome oil from the plains of Northern India. Journal of Young Pharmacists. 2009;1(4):312.

4. Singh S, Panda MK, Subudhi E, et al. Chemical composition of leaf and rhizome oil of an elite genotype Curcuma longa L. from South Eastern Ghats of Orissa. J Pharm Res. 2010;3(7):1630-1633.

5. Naz S, Jabeen S, Ilyas S, et al. Antibacterial activity of Curcuma longa varieties against different strains of bacteria. PakJ Bot. 2010;42(1):45562.

6. Aggarwal BB, Harikumar KB. Potential therapeutic effects of curcumin, the anti-inflammatory agent, against neurodegenerative, cardiovascular, pulmonary, metabolic, autoimmune and neoplastic diseases. Int J Biochem Cell Biol. 2009;41(1):40-59.

7. Niamsa N, Sittiwet C. Antimicrobial activity of Curcuma longa aqueous extract. Journal of Pharmacology and Toxicology. 2009;4(4):173-177.

8. Teow SY, Liew K, Ali SA, et al. Antibacterial action of curcumin against Staphylococcus aureus: a brief review. Journal of tropical medicine. 2016.

9. Ammon HP, Wahl MA. Pharmacology of Curcuma longa. Planta medica. 1991;57(01):1-7.

10. Tripathi AK, Prajapati V, Verma N, et al. Bioactivities of the leaf essential oil of Curcuma longa (var. ch-66) on three species of stored-product beetles (Coleoptera). J Econ Entomol. 2002;95(1):183-9.

11. Sánchez E, García S, Heredia N. Extracts of edible and medicinal plants damage membranes of Vibrio cholerae. Appl Environ Microbiol. 2010;76(20):6888-6894.

12. Yang N, Zhao M, Zhu B, et al. Anti-diabetic effects of polysaccharides from Opuntia monacantha cladode in normal and streptozotocininduced diabetic rats. Innovative food science \& emerging technologies. 2008;9(4):570-574.
13. Hameed ESS, Nagaty MA, Salman MS, et al. Phytochemicals, nutritionals and antioxidant properties of two prickly pear cactus cultivars (Opuntia ficus indica Mill.) growing in Taif, KSA. Food chemistry. 2014;160:3138 .

14. Clark WD, Brown GK, Mays RL. Flower flavonoids of Opuntia subgenus Cylindropuntia. Phytochemistry. 1980;19(9):2042-2043.

15. Lee JA, Jung BG, Lee BJ. Inhibitory effects of Opuntia humifusa on 7, 12-dimethyl-benz [a] anthracene and 12-O-tetradecanoylphorbol-13acetate induced two-stage skin carcinogenesis. Asian Pac J Cancer Prev. 2012; 13(9):4655-4660

16. Fernandez Lopez JA, Almela L. Application of high-performance liquid chromatography to the characterization of the betalain pigments in prickly pear fruits. J Chromatogr A. 2001;913(1):415-420.

17. Saenz C. Cladodes: A source of dietary fiber. Journal of the Professional Association for Cactus Development. 1998;2:117-123.

18. Fernández-López JA, Giménez PJ, Angosto JM, et al. A process of recovery of a natural yellow colourant from opuntia fruits. Food Technol Biotechnol. 2012; 50(2):246-251.

19. De Leo M, De Abreu MB, Pawlowska AM, et al. Profiling the chemical content of Opuntia ficus-indica flowers by HPLC-PDA-ESI-MS and GC/EIMS analyses. Phytochemistry Letters. 2010;3(1):48-52.

20. Castillo SL, Heredia N, Contreras JF, et al. Extracts of edible and medicinal plants in inhibition of growth, adherence, and cytotoxin production of Campylobacter jejuni and Campylobacter coli. J Food Sci. 2011;76(6):21-26.

21. Daun JK, Barthet VJ, Chornick TL. Structure, composition, and variety development of flaxseed. In Flaxseed in Human Nutrition, Second Edition. AOCS. 2003.

22. Oomah BD. Flaxseed as a functional food source. Journal of the Science of Food and Agriculture. 2001;81(9):889-894.

23. Harper CR, Edwards MJ, DeFilipis AP, et al. Flaxseed oil increases the plasma concentrations of cardioprotective (n-3) fatty acids in humans. $J$ Nutr. 2006;136(1):83-87.

24. Rabetafika HN, Van Remoortel V, Danthine S, et al. Flaxseed proteins: food uses and health benefits. International journal of food science \& technology. 2011;46(2):221-228.

25. Bhathena SJ, Ali AA, Haudenschild C, et al. Dietary flaxseed meal is more protective than soy protein concentrate against hypertriglyceridemia and steatosis of the liver in an animal model of obesity. $\mathrm{J}$ Am Coll Nutr. 2003;22(2):157-164.

26. Kristensen M, Jensen MG, Aarestrup J, et al. Flaxseed dietary fibers lower cholesterol and increase fecal fat excretion, but magnitude of effect depend on food type. Nutr Metab (Lond). 2012;9(1):8.

27. Madhusudhan B. Potential benefits of flaxseed in health and disease-A perspective. Agriculturae Conspectus Scientificus (ACS). 2009;74(2):6772.

28. Lowcock EC, Cotterchio M, Boucher BA. Consumption of flaxseed, a rich source of lignans, is associated with reduced breast cancer risk. Cancer Causes Control. 2013;24(4):813-816.

29. Touillaud MS, Thiébaut AC, Fournier A, et al. Dietary lignan intake and postmenopausal breast cancer risk by estrogen and progesterone receptor status. J Natl Cancer Inst. 2007;99(6):475-486.

30. Cowan ST, Steel KL. Cowan and Steel manual for the identification of medical bacteria. Cambridge University Press: London; 1974.

31. Parekh J, Jadeja D, Chanda S. Efficacy of Aqueous and Methanol Extracts of Some Medicinal Plants for Potential Antibacterial Activity. Turk J Biol. 2005;29:203-210 
32. Ruby J, Kuttan G, Babu KD, et al. Antitumor and oxidant activity of natural curcum- noids. Cancer Lett 1995;94(1):79-83.

33. Apisariyakul A, Vanittanakom N, Buddhasukh D. Antifungal activity of turmeric oil extracted from Curcuma longa (Zingiberaceae). J Ethnopharmacol. 1995;49:163-169.

34. Roth G, Chandra A, Nair M. Novel bioactivities of Curcuma longa constituents. J Nat Prod. 1998;61(4):542-545.

35. Ammon H, Safayhi H, Mack T, et al. Mechanism of antiinflammatory actions of curcumin and boswellic acids. J Ethnopharmacol 1993;38(23):113.

36. Bisset NG. Herbal Drugs and Phytopharmaceuticals. Boca Raton, FL: CRC Press; 1994.

37. Miller L, Murray WJ. Herbal Medicinals. A Clinician's Guide. Binghamton, NY: Pharmaceutical Products Press. 1998.

38. White LB, Foster S. The Herbal Drugstore. Emaus PA: Rodale Inc. 2000.

39. Young Joon S. Molecular mechanisms of chemopreventive effects of selected dietary and medicinal phenolic substances. Mutat Res. 1999;428(2):305-327.

40. El Feghali PA, Ibrahim R, Nawas T. Antibacterial activity of curcumin against Lebanese clinical isolates of Staphylococcus aureus. MOJ Toxicol. 2018;4(2):81-83.

41. Joe, B, Vijaykumar M, Lokesh BR. Biological properties of curcumincellular and molecular mechanisms of action. Critical Reviews in Food Science and Nutrition. 2004;44(2):97-111.

42. Parekh J, Karathia N, Chanda S. Screening of some traditionally used medicinal plants for potential antibacterial activity. Indian J. Pharm. Sci. 2006;68(6):832-834.

43. Zhanel GG, Hoban DJ, Harding GK. Subinhibitory antimicrobial concentrations: a review of in vitro and in vivo data. Canadian Journal of Infectious Diseases and Medical Microbiology.1992;3(4):193-201.'
44. Barwick VJ. Strategies for solvent selection - A literature review. Trends in Analytical Chemistry. 1997;16(6):293-309.

45. Ginestra G, Parker ML, Bennett RN, et al. Anatomical, chemical, and biochemical characterization of cladodes from prickly pear [Opuntia ficus-indica (L.) Mill.]. Journal of agricultural and food chemistry. 2009;57(21):10323-10330.

46. Fabrega J, Fawcett SR, Renshaw JC, et al. Silver nanoparticle impact on bacterial growth: effect of $\mathrm{pH}$, concentration, and organic matter. Environmental science \& technology. 2009;43(19):7285-7290.

47. Osorio Esquivel O, Ortiz Moreno A, Alvarez VB. Phenolics betacyanins and antioxidant activity in Opuntia joconostle fruits. Food Res Int. 2011:44:2160-2168.

48. Paiz RC, Juarez Flores BI, Aguirre RJR, et al. Glucose-lowering effect of xoconostle (Opuntia joconostle A. Web. Cactaceae) in diabetic rats. J. Med. Plants Res. 2010;4(22):2326-2333.

49. Schaffer S, Schmitt Schillig S, Muller WE, et al. Antioxidant properties of Mediterranean food plant extracts: Geographical differences. J. Physiol. Pharmacol. 2005;56 (Suppl. S1):115-124.

50. Pham Huy LAN, He H, Pham-Huy C. Green tea and health: an overview. J Food Agricul Environ. 2008;6(1):6-13.

51. Cui W, Mazza G. Physicochemical characteristics of flaxseed gum. Food Research International, 1996;29(4):397-402.

52. Gibson GR, Probert HM, Loo JV, et al. Dietary modulation of the human colonic microbiota: updating the concept of prebiotics. Nutrition Research Review. 2004;17(4):259-275.

53. EUCAST Discussion Document. Determination of minimum inhibitory concentrations (MICs) of antibacterial agents by broth dilution. Clin Microbiol Infect. 2003;9(8):1-7.

54. Iwu MW, Duncan AR, Okunji CO. New antimicrobials of plant origin In: Janick J, editor. Perspectives on new crops and new uses. Alexandria: ASHS Press; 1999. p. 457-462. 